\title{
Is Direct Seeding an Alternative to Transplanted Rice Culture and How Transplanted Rice Cultivars Perform under Direct Seeding?
}

\author{
B. Gangaiah ${ }^{1 *}$ and M.B.B. Prasad Babu
}

${ }^{1}$ Division of Natural Resource Management, ICAR-Central island Agricultural Research Institute, Port Blair 744105, Andaman \& Nicobar Islands, India Directorate of Rice Research, Rajendra Nagar, Hyderabad 500 030, India

*Corresponding author

\section{Keywords \\ Broadcast sowing, Drum seeding, Hybrid, Net income, Rice, Transplanting, Variety, Yield \\ Article Info \\ Accepted: \\ 04 April 2019 \\ Available Online: \\ 10 May 2019}

\section{A B S T R A C T}

Field study was made during 2012 kharif season (July- November) at Hyderabad with 12 rice cultivars (6 high yielding varieties; 6 hybrids) belonging to early, mid early and medium duration maturity group ( 2 varieties / hybrid each) in sub-plots under 3 establishment methods (transplanting, drum seeding and broadcasting) as main plots in split plot design with four replications. Data revealed that direct wet seeding of rice by broadcast on account of $31.7 \%$ higher tiller production incurring $9.81 \%$ reduction in number of grains/panicle and unaffected test weight of grains has $4.81 \%$ higher grain yield than transplanted rice $(6.65 \mathrm{t} / \mathrm{ha})$. The reductions in cost of production (Rs. 6975/ha) in broadcast rice owing to 25 man days reduction for transplanting operations coupled with $4.81 \%$ higher grain yields together have brought $33.2 \%$ higher net profits than transplanted rice (Rs. 32705). Drum seeding on account of reduced cost of production despite of no yield gains, have $24.8 \%$ higher net income than transplanted rice. Hybrids on average have $19.4 \%$ higher grain yield than the varieties $(6.12 \mathrm{t} / \mathrm{ha})$. This yield difference between a hybrid and variety was highest in early $(25.2 \%)$ followed by mid early $(19.1 \%)$ and medium maturity group (14.9\%). KRH-2 hybrid rice cultivation is most profitable (Rs. 42150) followed by PA 6201 hybrid owing to higher grain yields. Rice cultivar $x$ establishment method indicated that for Sahyadri-4 hybrid, transplanting is better to drum seeding while for Annada, IR-64 and Krishna hamsa varieties and for KRH-2 hybrid; broadcast seeding was promising. Crop duration is reduced by 12-13 days with direct seeding over transplanting. Per day productivity was highest with PA 6201, broadcast sowing.

\section{Introduction}

Rice (Oryza sativa L.) is the major staple crop of the country accounting for $39.64 \%$ of total food grain production (284.83 million tonnes) during 2017-18 (DOES, 2018). Over years, transplanted rice culture with high and stable yields has under assured irrigation has gained prominence. This labour intensive establishment system was highly suited to the labour surplus Asian countries including India till flag end of late $20^{\text {th }}$ century. Rapid 
industrialization, urbanization has created enormous employment opportunities in nonfarm sector. In rural areas too, the employment guarantee schemes like Mahatma Gandhi National Rural Employment Guarantee Act (MGNREGA) and food security programmes have not only made their wages dearer but also avoid tedious jobs like transplanting of rice. Higher wages for transplanting are eroding the profits of rice crop necessitating alternate methods of establishment in puddle soil. Eliminating the manual transplanting operation needing 238 man-hours/ha (Dixit and Khan, 2011) could affect savings anywhere between Rs. 750010000/ha. In this direction, mechanical transplanting is explored with good success though has limitations of incomplete transplanting of field on corners / turnover space of transplanter, difficult to use with small size blocks of rice fields and further it involves mat nursery raising. To avoid nursery raising and incomplete transplanting of field by machines, direct seeding of rice both dry (aerobic rice) and wet methods were looked at. Reduced duration of crop (7-12 days) under direct seeding adds to crop intensification in a year (Mondal et al., 2015). No specific varieties of rice are bred for direct seeding till date; hence, transplanted ecology varieties are used despite of their differential performance. The differential performance is more in case of hybrids. Hybrid rice cultivation in India is spread on 2.5 million ha in 2014 (Khandker and Gandhi, 2018) with 20-30\% higher yields over high yielding varieties (Banerjee and Pal, 2012). The altered management system (Direct seeding, saturation moisture at establishment, more weeds, altered fertilizer schedules, reduced crop duration etc.) may also lead to differential performance of cultivars. The challenges of enhanced weed pressure under saturation moisture regime at establishment stage (Chauhan 2012) are addressed through suitable herbicide (Choudhary and Anil Dixit,
2018). It is in this context of above challenges to direct seeding and solutions evolved, the performance of promising high yielding varieties and hybrids belonging to different maturity groups (early, mid early and medium) under direct seeding as compared to transplanting was assessed to answer the question that Is direct seeding an alternative to transplanted rice culture and how transplanted rice cultivars perform under direct seeding?.

\section{Materials and Methods}

A field investigation was conducted for during kharif season (July- November) of 2012 at research farm of Directorate of Rice Research, Rajendranagar, Hyderabad situated at $19^{\circ} \mathrm{N}$ latitude and $74^{\circ} \mathrm{E}$ longitude at an altitude of $700 \mathrm{~m}$ above mean sea level. The soil of the experimental site is clayey (Veritsol; Typic Pellustert) with $7.8 \mathrm{pH}$, EC $0.26 \mathrm{dS} / \mathrm{m}$ in 1:2.5 soil: water (Jackson, 1973) containing $0.65 \%$ organic carbon (Wakley and Black, 1943), $258 \mathrm{~kg} / \mathrm{ha} \mathrm{KMnO} 4$ extractable N (Subbiah and Asija, 1956), 392 $\mathrm{kg} / \mathrm{ha} \mathrm{NH}_{4} \mathrm{OAC}$ extractable $\mathrm{K}$, and $18 \mathrm{~kg} / \mathrm{ha}$ $0.5 \mathrm{M} \mathrm{NaHCO} 3$ extractable $\mathrm{P}$ (Olsen et al., 1956). Eighteen treatments formed by combination of three planting methods i.e. direct wet seeding of rice (DWSR), drum seeding (DS) and conventional manual transplanting in main plot and twelve varieties i.e. six hybrids 2 each of early, mid early and medium duration (DRRH-2, PA-6129, PA6201, Sahyadri-4, DRRH-3, KRH-2) and 6 varieties 2 each of early, mid early and medium duration (Annada, NDR-97, IR-64, Krishna hamsa, RPBio-226 and Jaya) in subplot were tested in split plot design and treatments were replicated thrice. The experimental field was thoroughly prepared by puddling thrice with power tiller followed by its precise levelling for quick drainage of water (both irrigation and rain water) in direct seeded rice. In drum seeding, 24 hour water 
soaked seed was sown in rows $20 \mathrm{~cm}$ apart using drum seeder where as in direct wet seeding, pre-germinated seed was broadcast sown. In both the direct seeding methods, a seed rate of $20 \mathrm{~kg} / \mathrm{ha}$ was used. Nursery was also sown on the same day of direct seeding. Eighteen days old rice seedlings were transplanted in rows $20 \mathrm{~cm}$ apart with a plant to plant spacing of $15 \mathrm{~cm}$ in a well prepared land as that of direct seeded rice mentioned above. A fertilizer schedule of $60-60-5 \mathrm{~kg} / \mathrm{ha}$ $\mathrm{P}-\mathrm{K}-\mathrm{Zn}$ as basal in last puddling and $120 \mathrm{~kg} \mathrm{~N}$ (applied in 3 equal splits at 5-30-55 days after transplanting/seeding) was followed. For weed management, pre-emergence application of butachlor (transplanted) and pyrazosulfuron ethyl immediately after transplanting / seeding and bi-spiribac sodium (25 days after transplanting/ seeding). In addition to the herbicides, a manual weeding was done at 35 days after seeding to remove uncontrolled weeds. Saturation moisture was maintained in DSR in the first week after seeding and the level of water was gradually increased as per the height of seedling and from $20^{\text {th }}$ DAS, $3 \mathrm{~cm}$ standing water was maintained. The field was dewatered at topdressing of $\mathrm{N}$ fertilizer and herbicide application. Thinning / gap filling were done in DSR on $10^{\text {th }}$ DAS. In transplanted rice, a standing water of $3 \mathrm{~cm}$ was maintained from transplanting time to soft dough stage. Growth, yield attributes, days to maturity and yield were recorded as per standard procedures. Economics were worked out taking the input prices and output (grain only; as straw is used as livestock feed by farmers). Minimum support price of rice grain (Rs. 12,500 tonne) was used. Cost of hybrid rice seed was taken as Rs. $250 / \mathrm{kg}$. A reduction of 25 man days in nursery and transplanting operations were taken in direct seeding methods as compared to transplanting method (30 man days). A cost of Rs. 300/ man day was used. The analysis of variance was done for all the information generated in SPD. The significance of treatment differences was compared by critical difference at 5\% level of significance $(\mathrm{P}=0.05)$ and statistical interpretation of treatments was done as per Gomez and Gomez (1984).

\section{Results and Discussion}

Growth and yield attributes data of rice as influenced by cultivar and establishment method are given in Table 1.

\section{Plant height and crop duration}

The data reveals that there were no significant differences in plant height of rice with in maturity group with the exception that KRH-2 has significantly taller plants than its medium duration counterparts. Both the direct seeding methods being at par with each other have produced significantly taller plants than the transplanted crop. The taller plants production under direct seeding by rice as compared to transplanting was ascribed higher plant density and longer duration of plants in the main field.

Crop duration differences are significant among maturity groups. However, in early maturity group, varieties took significantly lesser duration to mature than the hybrids. Crop duration differences between the earliest maturing (Annada) and late maturing variety (RP Bio-226) was 45 days. Direct seeding methods took 12.5 days lesser duration to maturity than the transplanted crop. The reductions in crop duration due to direct seeding as compared to transplanting are in conformity with the findings of Mondal et al., (2015).

\section{Yield attributes}

Yield attributed differed due to cultivar and establishment method (Table 1). Among the early group, PA-6129, hybrid has 
significantly higher panicle production than other three members of this maturity group. Two early hybrids (PA-6127 and DRRH-2) have heavier grains $(2.5-3.0 \mathrm{~g})$ than the two varieties. Mid early group did not differ for grains/panicle. Panicle production and test weight was markedly higher in PA-6201 and Sahyadri-4 than others in the group. Krishna hamsa, with lowest test weight has proved its fine grain quality. Among the late maturity group, KRH-2 being at par with RP-Bio-226 has recorded significantly higher number of panicles. KRH-2 has the highest grains/ panicle than other three cultivars of the group. RP-Bio-226 has lowest test weight among the group.

Among establishment methods, significant differences were seen for number of panicles and grains/panicle. Direct wet seeding and drum seeded rice has recorded 31.7 and $16.1 \%$ higher panicle numbers $/ \mathrm{m}^{2}$ than transplanting (293.7). Further, wet seeded rice has $12.9 \%$ higher panicle numbers $/ \mathrm{m}^{2}$ than drum seeded rice. Transplanted rice has significantly higher number of grains/ panicles than both the direct seeding methods that have similar values. The higher number of panicles in direct seeded rice was ascribed to more number of plants/ unit area as compared to fixed number of plants in transplanted crop $\left(33.3 / \mathrm{m}^{2}\right)$. Due to maintenance of line to line $(20 \mathrm{~cm})$ and seed to seed distance $(8 \mathrm{~cm})$, drum seeded rice has lower plants /unit area $\left(62.5 / \mathrm{m}^{2}\right)$ than the manually broadcast wet seeded crop (85 plants $/ \mathrm{m}^{2}$ ). When we counted the tiller production/ hill, transplanting method of establishment has the highest values, but when estimated per unit area $\left(\mathrm{m}^{2}\right)$, panicles were highest in direct seeding methods. Due to more population/ unit area, lesser number of grains was produced in direct seeded rice. Test weight did not differ due to establishments methods. Similar higher tiller production in direct seeding as compared to transplanting was reported by Lavanya et al., (2018) and Rana et al., (2014)

\section{Grain yield}

Grain yield of rice was greatly affected by cultivar, method of establishment and their interaction (Table 2). The data reveals that rice has an average grain production of 6.72 t/ha. Rice cultivars grain yield followed the crop duration, i.e., longer the duration, higher the yield with few exceptions. Among the cultivars, medium duration hybrid, KRH-2 out yielded all other hybrids and varieties by 0.86 (next best performing hybrid: PA-6201) $2.02 \mathrm{t} / \mathrm{ha}$ (over poorest performer: Annada). Highest panicle, grains/ panicle production have contributed to KRH-2 superior performance. RP-Bio-226 owing to least test weight (14.9 g) despite of high panicle and grains/panicle production poor performance. Same reason holds true for Krishna hamsa. Hybrids on average have $19.4 \%$ higher grain yield than the varieties (6.12 t/ha). The yield difference between a hybrid and variety was highest in early group (25.2\%) followed by mid early (19.1\%) and least with medium group (14.9\%). In medium group, Jaya variety has at par performance as that of hybrid (DRRH-3). Low grain yields of rice varieties despite of higher number of panicles and grains/panicle on account of low test weight of the current study were corroborated by the results of Sharath (2017).

Direct wet seeded (broadcast) rice has significantly higher grain yield than drum seeded and transplanted rice. Direct wet seeding has recorded 0.44 and 0.32 t/ha higher grain yield than DS (6.53 t/ha) and TP rice $(6.65 \mathrm{t} / \mathrm{ha})$.

Higher number of panicles in direct wet seeding has more than offsetting the lower number of grains/panicle has produced higher grain yields than transplanted rice. Lack of 
transplanting shock to seedlings in direct seeding might have also contributed to better tiller production and thus yields. Similar results were reported by Lavanya et al., (2018) and Manjunath et al., (2009).

The interaction effect of cultivar and establishment method reveals that for Sahyadri-4 hybrid transplanting is better to drum seeding. For Annada, IR-64 and Krishna hamsa varieties and for KRH-2, hybrid; direct wet seeding was promising establishment method. Further, NDR-97 and PA-6201 have better performance under direct wet seeding. Higher tiller production of above cultivars with direct seeding as compared to transplanting has resulted in higher grain yields.

\section{Per day productivity}

Per day productivity of rice as influenced by cultivar and establishment methods was given in Figure 1a \& Figure 1b. Among the cultivars, PA-6129 has significantly higher per day productivity values than all other cultivars while RP-Bio-226 has the least values. Hybrids on an average have $8.0 \mathrm{~kg} / \mathrm{ha}-$ day higher per day productivity than the varieties (52.5). All hybrids except DRRH-3 have higher per day productivity values than varieties.

Table.1 Yield attributes of rice cultivars under different methods of establishment

\begin{tabular}{|c|c|c|c|c|c|}
\hline Treatment & $\begin{array}{c}\text { Number } \\
\text { of } \\
\text { panicles/ } \\
\mathrm{m}^{2}\end{array}$ & $\begin{array}{l}\text { Number } \\
\text { of grains/ } \\
\text { panicle }\end{array}$ & $\begin{array}{c}\text { Test } \\
\text { weight } \\
(\mathrm{g})\end{array}$ & $\begin{array}{l}\text { Plant } \\
\text { height } \\
(\mathrm{cm})\end{array}$ & $\begin{array}{l}\text { Crop } \\
\text { duration } \\
\text { (seed to } \\
\text { seed) }\end{array}$ \\
\hline \multicolumn{6}{|l|}{ Cultivar } \\
\hline Annada $^{\mathrm{aA}}$ & 311.0 & 88.0 & 20.7 & 92.0 & 93 \\
\hline NDR-97 ${ }^{\mathrm{aA}}$ & 302.0 & 90.4 & 20.5 & 86.5 & 96 \\
\hline DRRH-2 ${ }^{\mathrm{aB}}$ & 315.0 & 87.9 & 23.7 & 88.9 & 106 \\
\hline PA-6129 & 345.5 & 90.8 & 23.0 & 90.5 & 109 \\
\hline IR64 ${ }^{\mathrm{bA}}$ & 323.0 & 97.5 & 19.1 & 89.4 & 119 \\
\hline Krishna hamsa ${ }^{\text {bA }}$ & 344.7 & 89.3 & 16.8 & 93.7 & 124 \\
\hline PA-6201 ${ }^{\text {bB }}$ & 351.0 & 92.8 & 20.3 & 94.3 & 121 \\
\hline Sahyadri- $4^{\mathrm{bB}}$ & 339.8 & 98.4 & 22.9 & 95.0 & 120 \\
\hline RP bio- $226^{\mathrm{cA}}$ & 368.9 & 105.0 & 14.9 & 98.1 & 138 \\
\hline Jaya $^{\text {cA }}$ & 338.4 & 89.4 & 17.4 & 99.3 & 134 \\
\hline DRRH- $3^{\mathrm{cB}}$ & 358.6 & 98.8 & 23.9 & 95.2 & 136 \\
\hline $\mathrm{KRH}-2^{\mathrm{cB}}$ & 380.1 & 158.4 & 23.7 & 109.8 & 137 \\
\hline $\mathrm{CD}(\mathrm{P}=0.05)$ & 16.05 & 9.32 & 1.10 & 6.4 & 8.5 \\
\hline \multicolumn{6}{|l|}{ Establishment method } \\
\hline Drum Seeding & 341.0 & 95.6 & 20.52 & 96.2 & 116 \\
\hline Wet Seeding & 385.0 & 94.4 & 20.54 & 98.5 & 115 \\
\hline Transplanting & 293.7 & 106.0 & 20.68 & 87.4 & 128 \\
\hline $\mathrm{CD}(\mathrm{P}=0.05)$ & 13.91 & 8.63 & NS & 5.8 & 7.9 \\
\hline Interaction & $\mathrm{S}$ & NS & NS & NS & NS \\
\hline
\end{tabular}


Table.2 Performance of rice varieties and hybrids of varying maturity groups ( $\mathrm{t} / \mathrm{ha}$ ) under different methods of establishment

\begin{tabular}{|c|c|c|c|c|}
\hline \multirow[t]{2}{*}{ Rice cultivar } & \multicolumn{3}{|c|}{ Establishment method } & \multirow[b]{2}{*}{ Mean } \\
\hline & Drum Seeding & Wet Seeding & Transplanting & \\
\hline Annada $^{\text {aA }}$ & 5.15 & 5.80 & 5.27 & 5.41 \\
\hline NDR-97 ${ }^{\text {aA }}$ & 5.44 & 5.92 & 5.51 & 5.63 \\
\hline DRRH-2 ${ }^{\text {aB }}$ & 6.23 & 6.54 & 6.32 & 6.36 \\
\hline PA-6129 & 7.26 & 7.58 & 7.53 & 7.46 \\
\hline IR64 $^{\mathrm{bA}}$ & 5.83 & 6.53 & 5.97 & 6.11 \\
\hline Krishna hamsa $^{\text {bA }}$ & 6.04 & 6.80 & 6.24 & 6.36 \\
\hline PA-6201 ${ }^{\mathrm{bB}}$ & 7.43 & 7.86 & 7.42 & 7.57 \\
\hline Sahyadri- $4^{b B}$ & 7.07 & 7.18 & 7.57 & 7.28 \\
\hline RP bio-226 ${ }^{\text {cA }}$ & 6.27 & 6.45 & 6.19 & 6.31 \\
\hline Jaya $^{\text {cA }}$ & 6.77 & 7.13 & 6.86 & 6.92 \\
\hline DRRH-3 ${ }^{\mathrm{cB}}$ & 6.59 & 7.01 & 6.72 & 6.77 \\
\hline KRH-2 ${ }^{\mathrm{cB}}$ & 8.31 & 8.83 & 8.14 & 8.43 \\
\hline Mean & 6.53 & 6.97 & 6.65 & 6.72 \\
\hline \multirow[t]{2}{*}{$\mathrm{CD}(\mathrm{P}=0.05)$} & $\begin{array}{l}\text { Methods of } \\
\text { establishment } \\
\text { (M) }\end{array}$ & Cultivar (C) & $\begin{array}{l}\text { Interaction }(\mathrm{C} \\
\text { at same } \mathrm{M})\end{array}$ & $\begin{array}{l}\text { C at same or } \\
\text { different } \mathrm{M}\end{array}$ \\
\hline & 0.295 & 0.236 & 0.407 & 0.485 \\
\hline
\end{tabular}

Table.3 Performance of rice varieties and hybrids of varying maturity groups ( $t / h a)$ under different methods of establishment

\begin{tabular}{|c|c|c|c|}
\hline \multirow[t]{2}{*}{ Treatment } & \multicolumn{3}{|c|}{ Economics (Rs/ha) } \\
\hline & Gross income & Cost of cultivation & Net income \\
\hline \multicolumn{4}{|l|}{ Cultivar } \\
\hline Annada $^{\text {aA }}$ & 67625 & 40575 & 27050 \\
\hline NDR-97 ${ }^{\mathrm{aA}}$ & 70375 & 42225 & 28150 \\
\hline DRRH-2 ${ }^{\mathrm{aB}}$ & 79500 & 47700 & 31800 \\
\hline PA-6129 & 93250 & 55950 & 37300 \\
\hline IR64 $4^{\mathrm{bA}}$ & 76375 & 45825 & 30550 \\
\hline Krishna hamsa $^{\text {bA }}$ & 79500 & 47700 & 31800 \\
\hline PA-6201 ${ }^{\text {bB }}$ & 94625 & 56775 & 37850 \\
\hline Sahyadri-4 ${ }^{\text {bB }}$ & 91000 & 54600 & 36400 \\
\hline RP bio-226 ${ }^{\text {cA }}$ & 78875 & 47325 & 31550 \\
\hline Jaya $^{\text {cA }}$ & 86500 & 51900 & 34600 \\
\hline DRRH-3 ${ }^{\mathrm{cB}}$ & 84625 & 50775 & 33850 \\
\hline KRH-2 ${ }^{\text {cB }}$ & 105375 & 63225 & 42150 \\
\hline $\mathrm{CD}(\mathrm{P}=0.05)$ & & & 2900 \\
\hline \multicolumn{4}{|l|}{ Establishment method } \\
\hline Drum Seeding & 81625 & 40813 & 40813 \\
\hline Wet Seeding & 87125 & 43563 & 43563 \\
\hline Transplanting & 83125 & 50358 & 32705 \\
\hline $\mathrm{CD}(\mathrm{P}=0.05)$ & & & 2290 \\
\hline
\end{tabular}


Fig.1a\&b Per day productivity of rice as affected by cultivars \& per day productivity of rice as affected by establishment method

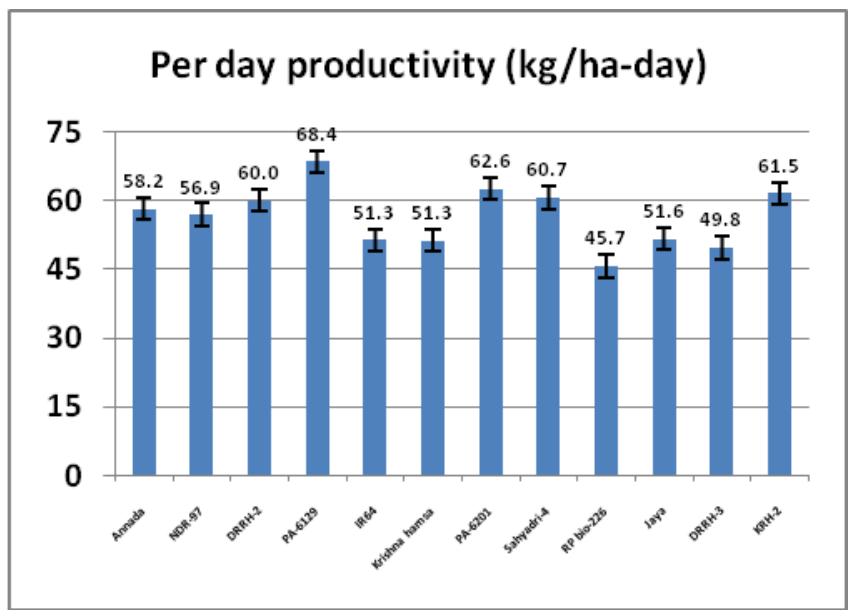

Early varieties / hybrids have highest per day productivity than their mid early and medium duration group counter parts. Among establishment methods, direct seeding methods have 4.3 (drum seeding) to 8.6 $\mathrm{kg} /$ ha-day higher per productivity than transplanting rice $(52.0 \mathrm{~kg} /$ ha-day $)$. Higher grain yield of wet seeding and lesser crop duration (13 days) and similar yields but lesser duration of crop (drum seeding) than transplanting has resulted in above per day productivity differences.

\section{Economics}

Economics were calculated based on grain yield and reduced (labour savings: Rs. 7500/ha due to direct seeding) or increased cost (hybrid seed: Rs. 4600/ha) of production (Table 3). Direct wet seeding and drum seeding have excluded the nursery and transplanting operations on an average have saved 25 labour/ha over transplanting method of rice culture (30 man days). Rice hybrids on account of their higher seed costs (Rs. $250 / \mathrm{kg}$ ) as compared to a variety (Rs. 30/kg) have Rs. 4600/ha higher cost of production. Net income (Rs/ha) indicates that KRH-2 hybrid rice cultivation is most economically rewarding. Direct seeding can enhance rice

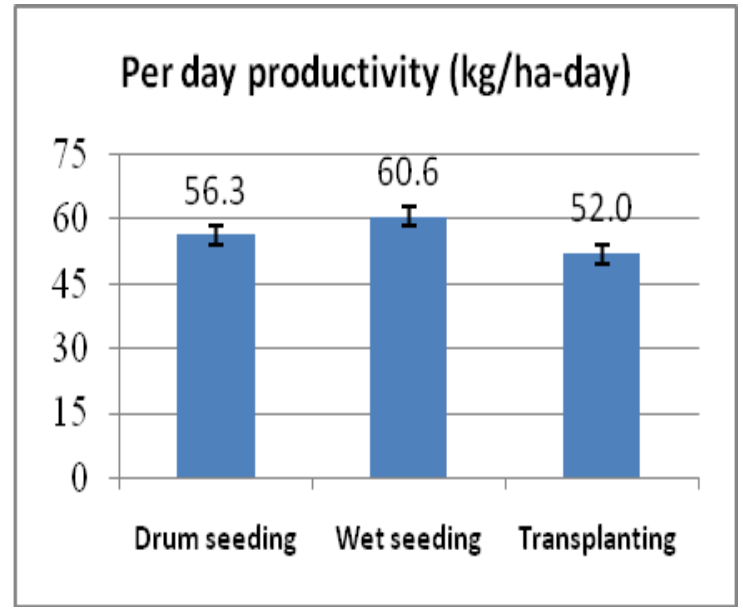

cultivation profits by Rs. 8108 *drum seeding) and 10858 (wet seeding) than transplanted rice,

In conclusion, study has established that hybrids and direct wet seeding by broadcast followed by drum seeding are economically viable alternatives to laborious transplanting and differential performance of cultivars with establishment methods emphasises on the need for use of such material existing now in transplanted ecology till specific varieties are evolved for direct seeding.

\section{References}

Banerjee, H. and Pal, S. 2012. Response of hybrid rice to nutrient management during wet season. Oryza, 49: 108-111.

Chauhan, Bhagirath S. 2012. Weed ecology and wed management for dry seeded rice in Asia. Weed Technology 26(1): 1-13.

Choudhary, V.K. and Anil Dixit. 2018. Herbicide weed management effect on weed dynamics, crop growth and yield in direct-seeded rice. Indian Journal of Weed Science 50(1): 6-12.

Dixit, J. and Khan, J.N. 2011. Comparative field evaluation of self-propelled paddy transplanter with hand transplanting in valley lands of Kashmir region. 
Agricultural Mechanization in Asia, Africa, and Latin America, 42(2): 14-18.

DOES (Directorate of Economics and Statistics). 2018. Pocket Book of Agricultural Statistics -2018. Government of India Ministry of Agriculture \& Farmers Welfare Department of Agriculture, Cooperation \& Farmers Welfare Directorate of Economics \& Statistics New Delhi.

Gomez, K. A. and A. A. Gomez. 1984. Statistical Procedures for Agricultural Research. John Wiley and Sons, Inc. London, UK, $\left(2^{\text {nd }} \mathrm{Ed}\right)$.

Jackson, M.L. 1973. Soil Chemical Analysis. Pentice Hall of India Pvt. Ltd., New Delhi.

Khandker, V and Gandhi, V P. 2018. Postadoption experience of hybrid rice in India: farmers' satisfaction and willingness to grow. Agricultural Economics Research Review 31(1): 95104.

Lavanya, N., M. Malla Reddy, M., Revathi, P. and Padmaja, G. 2018. Influence of different Establishment methods, varieties and $\mathrm{N}$ levels on growth and yield of late sown rice in Telangana state. International Journal of Current Microbiology and Applied Sciences 7(6): 1982-1993.

Manjunatha, M.V., Masthana Reddy, B.G and Joshi, V.R. 2009. Performance of rice (Oryza sativa) under different methods of establishment in Tungabhadra canal command, Karnataka. Karnataka Journal of Agricultural Sciences. 22(5): 11511152.

Mondal, M.K., Saha, N.K., Ritu, S.P., Paul, P.L.C., Sharifullah, A.K.M., Humphreys,
E., Tuong, T.P. and Rashid, M.A. 2015. Optimum sowing window for boro cultivation in the coastal zone of Bangladesh. pp. 342-360. In: Revitalizing the Ganges Coastal Zone: Turning Science into Policy and Practices Conference Proceedings. Colombo, Sri Lanka: CGIAR Challenge Program on Water and Food (CPWF), Humphreys, E., T.P. Tuong, M.C. Buisson, I. Pukinskis and M. Phillips (Eds). 600p.

Olsen, S.R., Cole, C.V., Watanabe, F.S. and Dean, L.A. 1954. Estimation of available phosphorus in soils by extraction with sodium bicarbonate. USDA Circular 939:1-19. Gov. Printing Office, Washington D.C.

Rana, M., Md. Abdullah Mamun., Afruz Zahan., Md. Nayeem Ahmed and Md. Abdul Jalil Mridha. 2014. Effect of planting methods on the yield and yield attributes of short duration aman Rice. American Journal of Plant Sciences. 5: 251-255.

Sharath, M. 2017. Performance of different rice varieties under alternate wetting and drying method of water management. M.Sc. Dissertation, Professor Jayasankar Telengana State Agricultural University, Hyderabad.

Subbiah, B.V. and Asija, G. L. 1956. A rapid procedure for estimation of available nitrogen in soils. Current Science 25 (8): 259-260

Wakley, A. and Black, I.A. 1943. An examination of the Degtejareff method for determining soil organic matter and a proposed modification of the chromic acid titration method. Soil Science 37: 29.

\section{How to cite this article:}

Gangaiah, B. and Prasad Babu, M.B.B. 2019. Is Direct Seeding an Alternative to Transplanted Rice Culture and How Transplanted Rice Cultivars Perform under Direct Seeding? Int.J.Curr.Microbiol.App.Sci. 8(05): 213-220. doi: https://doi.org/10.20546/ijcmas.2019.805.026 